\title{
Heavy Metal Removal in a Constructed Wetland and Benefits for the Development of the Toad Bufo raddei
}

\author{
Wan-tong Si ${ }^{1,2}$, Wen-ya Zhang ${ }^{1}$, Yue Lv', Feng Yang', Ju-mei Liü, ${ }^{1,2}$ Ying-mei Zhang'* \\ 'Gansu Key Laboratory of Biomonitoring and Bioremediation for Environmental Pollution, \\ School of Life Sciences, Lanzhou University, Lanzhou, 730000, PR China \\ ${ }^{2}$ The Institute of Bioengineering and Technology, Inner Mongolia Scientific and Technical University, \\ Baotou, 014010, PR China
}

Received: 13 April 2014

Accepted: 8 July 2014

\begin{abstract}
Heavy metal (HM) pollution in aquatic environments is of worldwide concern because of the toxicities of HMs in animals and humans. Constructed wetlands (CWs) have successfully been used as cost-effective natural systems to remove various contaminants. However, the effects of $\mathrm{CW}$ on the survival of animals have not been studied in any depth. We established a CW to remove HMs from water in Baiyin City, in the upper Yellow River (YR) region, which has a highly developed mining industry. The HM removal efficiency of CW as well as its effect on the development of the toad Bufo raddei were studied. The HM removal efficiencies by the $\mathrm{CW}$ were in the order $\mathrm{Cd}>\mathrm{Pb}>\mathrm{Zn}>\mathrm{Cu}$, and the decrease of the $\mathrm{HM}$ concentrations in the water also caused the decrease of the HM concentrations in B. raddei toads living in the CW. The toads in the CW had larger body sizes and less oxidative stress than toads living in the YR, and no malformations were found in the toads living in the $\mathrm{CW}$. These results indicate that $\mathrm{CW}$ systems such as that used in this study could protect amphibians from developmental problems caused by HM pollution. We recommend that $\mathrm{CW}$ systems are used to treat polluted water and protect amphibians.
\end{abstract}

Keywords: constructed wetland, heavy metal pollution, Bufo raddei, removal efficiency, protective effect

\section{Introduction}

Constructed wetlands (CWs) are highly efficient ecological systems that are used around the world for treating wastewater from a range of sources, including domestic, mining, and industrial wastewater [1]. Interest in CWs has been increasing because of its operational simplicity and cost efficiency compared with traditional wastewater treatment systems [2]. In recent years, CWs have drawn attention for their ability to remove heavy metals (HMs) from

\footnotetext{
*e-mail: ymzhang@1zu.edu.cn
}

wastewater [3, 4], in addition to their previous use in treating organic substances and nutrients. Several attempts have been made to investigate the influences of a number of factors on $\mathrm{CW}$ purification processes for water contaminated with HMs [5, 6]. However, the effects of $\mathrm{CW}$ on the survival of animals have not been studied in any depth.

The development of industries like mining and smelting have led to serious and increasing HM pollution, especially in developing countries [7]. The Yellow River (YR) is the largest freshwater ecosystem in northern China. It provides water for $12 \%$ of the population of China and is used to irrigate $12 \%$ of Chinese arable land. However, the worst YR 
water crisis in history is currently occurring, with about two thirds of the YR being heavily polluted with industrial waste [8]. Huge volumes of pollutants, mainly HMs, are discharged into the upper YR, especially in Lanzhou and Baiyin, which are the two most polluted cities in China [9], affecting the organisms living in the river [10].

Amphibians often serve as sentinels for environmental hazards because of their particular physiological characteristics and life histories $[11,12]$. Their highly permeable skins mean that dermal uptake of chemicals is two orders of magnitude faster in amphibians than in mammals [13]. Tadpoles are particularly useful in environmental monitoring because they develop a complete immune system and a complex circulatory system that both mature within days, rather than the years these systems take to develop in humans. Amphibians such as Bufo boreas and Rana sylvatica have been shown to be sensitive indicators of wetland quality [14], and antioxidative responses and oxidative stress levels in toads have been used as bio-indicators for pollutant exposure $[15,16]$. Environmental pollution is currently believed to be one of the main factors contributing to declining populations and increasing malformation rates in amphibians [17]. Bufo raddei is the most common toad species in the upper YR region, and its spawning adults and developing tadpoles are likely to be exposed to a range of pollution associated with industrial development [18].

The main HM contaminants in the YR water in the Baiyin Region (BYR), an industrial city affected by high levels of HM pollution because of the rapid expansion of non-ferrous metal mining and smelting, are cadmium $(\mathrm{Cd})$, copper $(\mathrm{Cu})$, lead $(\mathrm{Pb})$, and zinc $(\mathrm{Zn})$ [19], which have a range of potential toxic mechanisms in organisms. Previous studies have demonstrated that water pollution in Lanzhou and the BYR can cause high rates of abnormal development and malformation in B. raddei [18], and that this will influence the fitness, growth, and overwinter survival of individual toads [20].

In the present study, we established a CW in Silong town, BYR, with the aim of evaluating the efficiency with which the CW removed HMs from the YR water, and, more importantly, to assess the protective effect the CW had on the development of toads by removing pollutants. To the best of our knowledge, this study is the first one to appreciate the role of $\mathrm{CW}$ on the development of amphibians in polluted areas.

\section{Materials and Methods}

\section{Site Description}

The CW and the YR sampling sites were in Silong Town $\left(36^{\circ} 25.639 \mathrm{~N}, 104^{\circ} 23.428 \mathrm{E}\right)$ in the BYR (Fig. 1). Baiyin city is $75 \mathrm{~km}$ from Lanzhou, and was one of the first non-ferrous metal smelting and processing areas in China. Large amounts of domestic and industrial wastewater from Baiyin city are discharged into the YR at Silong town, through the East Ditch and the West Ditch, leading to high levels of pollution in the water and soil in the area.

\section{Wetland Design}

The CW was $18 \mathrm{~m} \times 15 \mathrm{~m}$ and $1 \mathrm{~m}$ deep, and contained $20 \mathrm{~cm}$ of homogenous soil planted with cattails Typha angustifolia, a widespread species in the BY, in March. The cattails were transplanted into the $\mathrm{CW}$ from a local river bank, with a density of 80-90 plant $/ \mathrm{m}^{2}$. The water depth in the $\mathrm{CW}$ was $0.5 \mathrm{~m}$ and the hydraulic retention time was $3 \mathrm{~d}$. The substrate soil used in the CW is gray calcareous from a wasteland in the upper mountain slope in BY city that has been tested to be relatively unpolluted [19]. The CW was surrounded by gauze during the experiment to prevent toads entering.

\section{Sampling and Preparation}

Water and Wetland Substrate

Water and wetland substrate samples were collected randomly from the $\mathrm{CW}$ or the YR at 5 different sample sites

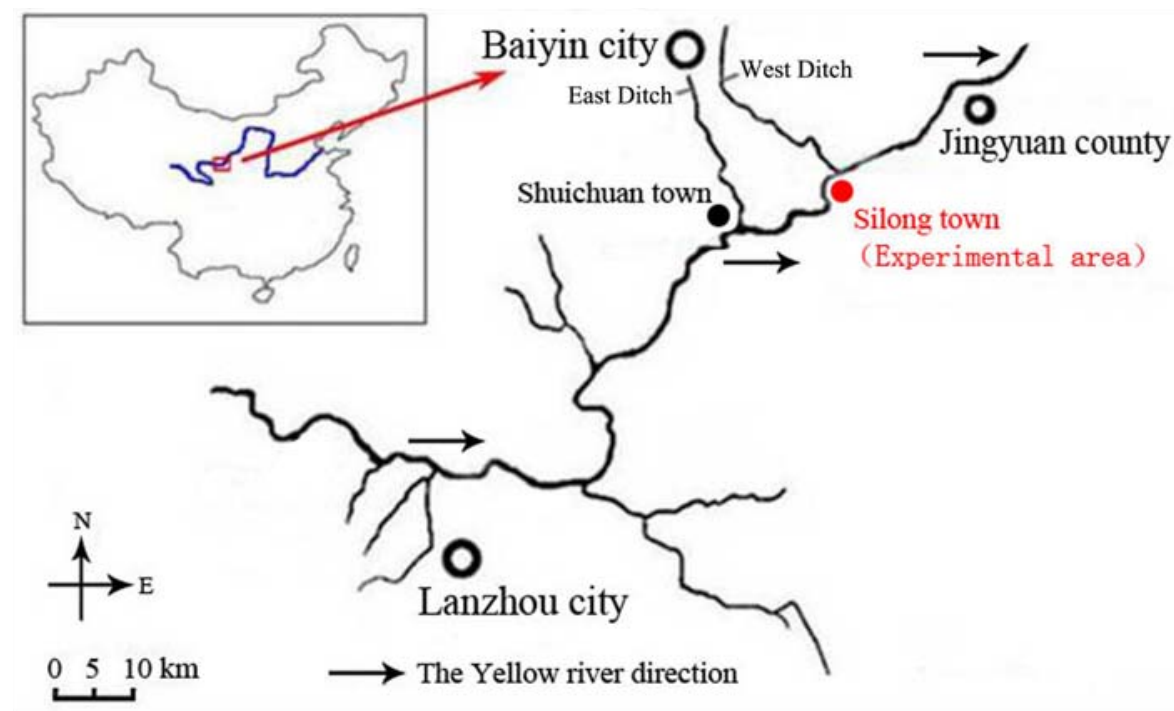

Fig. 1. Location of the experimental area in the Baiyin Region, China. 
at times when the toads reached different life stages (basically one time per month); all the samples were assayed in triplicate. Water samples were collected in accordance with published technical specifications for monitoring surface water and wastewater (HJ/T 91-2002) [21]. Water samples were acidified with $5 \% \mathrm{HNO}_{3}$ before being stored in clean polyethylene bottles at $4^{\circ} \mathrm{C}$ for $\mathrm{HM}$ analysis. Wetland substrate was collected from $0-20 \mathrm{~cm}$, air-dried at room temperature, and passed through a $1.0 \mathrm{~mm}$ sieve before the HMs were determined [22].

\section{Toads}

All of the toads that were put into the $\mathrm{CW}$ were collected from the local environment in early April, before the breeding season. During the experiment, toads were collected from the YR and the $\mathrm{CW}$, at random, at different life stages [23], which were stage I (Zhao's stage 26/27: postembryonic development begins), stage II (Zhao's stage 32/33: five hind toes emerged), stage III (Zhao's stage 37/38: more than half of the tail reabsorbed), stage IV (metamorphism completed), and stage $\mathrm{V}$ (a month after metamorphism completed). The toads were transferred to the laboratory, euthanized by pithing [24], and their liver coefficients (the liver to total body weight ratio) measured. Blood was collected and the reactive oxygen species (ROS) contents, total antioxidant capacity (T-AOC), and DNA oxidative damage were analyzed. For HM analysis, toad samples from the $\mathrm{CW}$ and the $\mathrm{YR}$ were randomly chosen at different life stages, and were oven dried at $70^{\circ} \mathrm{C}$ for $72 \mathrm{~h}$, then ground and passed through a $1.0 \mathrm{~mm}$ sieve before their HM contents were determined.

\section{Sample Analysis}

For all the following experiments, toads were caught randomly from $\mathrm{CW}$ or the $\mathrm{YR}$, and all the samples were assayed in triplicate.

\section{HM Analysis}

HM concentrations in water, wetland substrate, and toad samples were analyzed using inductively coupled plasma-atomic emission spectroscopy (IRIS advantage; Thermo Electron, Waltham, MA, USA) at Lanzhou University.

\section{Liver Coefficient Analysis}

After a toad was euthanized, its liver was removed and washed with phosphate-buffered saline (PBS), wiped with a filter paper to remove excess liquid, and weighed. The liver coefficient was determined as the ratio of liver weight to total body weight.

\section{ROS Content Analysis}

The ROS contents were determined using 2',7'-dichlorofluorescein diacetate (DCFH-DA), following the manu- facturer's (Beyotime Institute of Biotechnology, Jiangsu, China) recommendations, which were, briefly, as follows: 1 $\mathrm{mL}$ of blood cell suspension (about $10^{5}-10^{6}$ cell $/ \mathrm{mL}$ ) was washed twice with pre-cooled PBS $(\mathrm{pH}=7.4), 5 \mu \mathrm{L}$ of DCHF-DA was added, then the sample was cultivated in an incubator for $30 \mathrm{~min}$ and washed twice with PBS. The fluorescence intensity was measured using a fluorospectrophotometer and the ROS contents were expressed as average fluorescence intensity (U) per 10,000 cells.

\section{T-AOC Test}

The liver samples were weighed and homogenized in normal saline $(0.65 \%)$, and $10 \%$ of the homogenate was centrifuged at $2500 \mathrm{rpm}$ for $10 \mathrm{~min}$. The supernatant was used for T-AOC analysis using a test kit (Nanjing Jiancheng Bioengineering Institute, Nanjing, China), following the appropriate guidelines. The total protein content was measured on another aliquot using the burette method. The final T-AOC was expressed in units per milligram of liver protein (U/mg pro), a unit being defined as $1.0 \mathrm{mg}$ of liver protein giving an absorbance (OD520 nm) increase of $0.01 / \mathrm{min}$ at $37^{\circ} \mathrm{C}$.

\section{DNA Oxidative Damage Analysis}

The oxidative damage to the genomic DNA in the blood was assessed using the comet assay (single-cell gel electrophoresis assay), and was assumed to indicate genetic damage caused by exposure to environmental pollutants [18]. The degree of DNA oxidative damage was analyzed using a previously published method [25] and presented as the percentage of DNA found in the tail.

\section{Statistical Analysis}

Statistical analyses were carried out using SPSS 17.0 software (SPSS, Inc., Chicago, IL, USA). Results are expressed as the mean \pm standard deviation. One-way ANOVA and Duncan tests were used to compare the data. $\mathrm{P}<0.05$ was considered to indicate statistical significance and $\mathrm{P}<0.01$ to indicate a high level of statistical significance.

\section{Results and Discussion}

\section{Effect of CW on HM Removal from the YR Water}

A summary of the concentrations of the major contaminations in the water samples from the $\mathrm{YR}$ and $\mathrm{CW}$ is given in Table 1. The concentration of the HMs in the water from the $\mathrm{CW}$ system were much lower than that from the YR throughout the experimental period. The average removal rates (RRs) in the $\mathrm{CW}$ were $86.2 \%, 61.7 \%, 82.9 \%$, and $76.7 \%$ for $\mathrm{Cd}, \mathrm{Cu}, \mathrm{Pb}$, and $\mathrm{Zn}$, respectively, (that is, in the order $\mathrm{Cd}>\mathrm{Pb}>\mathrm{Zn}>\mathrm{Cu}$ ), showing that the $\mathrm{CW}$ removed the HMs from the YR water efficiently. Importantly, the con- 
Table 1. Heavy metal concentrations $(\mu \mathrm{g} / \mathrm{L})$ in water $(\mathrm{n}=3)$ from the Yellow River $(\mathrm{YR})$ and the constructed wetland $(\mathrm{CW})$ at different developmental stages (I-V) of Bufo raddei, and the removal rates (RRs) of the CW.

\begin{tabular}{|c|c|c|c|c|c|c|c|}
\hline & & I & II & III & IV & V & Mean \\
\hline \multirow{3}{*}{$\mathrm{Cu}$} & YR & $21.10 \pm 3.70$ & $18.20 \pm 4.40$ & $12.80 \pm 3.10$ & $10.30 \pm 1.70$ & $12.20 \pm 2.10$ & 14.90 \\
\hline & $\mathrm{CW}$ & $7.20 \pm 1.80$ & $6.30 \pm 2.10$ & $5.70 \pm 0.90$ & $4.30 \pm 1.20$ & $5.10 \pm 1.40$ & 5.70 \\
\hline & $\mathrm{RR}$ & $65.90 \%$ & $65.40 \%$ & $55.50 \%$ & $58.30 \%$ & $58.20 \%$ & $61.70 \%$ \\
\hline \multirow{3}{*}{$\mathrm{Zn}$} & YR & $32.60 \pm 3.40$ & $58.10 \pm 4.90$ & $16.90 \pm 1.80$ & $15.60 \pm 2.00$ & $14.00 \pm 4.10$ & 25.40 \\
\hline & $\mathrm{CW}$ & $6.40 \pm 0.39$ & $9.60 \pm 0.52$ & $5.90 \pm 0.70$ & $4.30 \pm 0.30$ & $3.40 \pm 0.80$ & 5.90 \\
\hline & $\mathrm{RR}$ & $80.40 \%$ & $83.50 \%$ & $65.10 \%$ & $72.40 \%$ & $75.70 \%$ & $76.70 \%$ \\
\hline \multirow{3}{*}{$\mathrm{Pb}$} & YR & $46.70 \pm 3.80$ & $42.60 \pm 4.20$ & $39.70 \pm 5.30$ & $29.30 \pm 3.80$ & $42.00 \pm 7.30$ & 40.10 \\
\hline & $\mathrm{CW}$ & $6.30 \pm 1.50$ & $6.40 \pm 0.80$ & $6.80 \pm 2.00$ & $5.80 \pm 0.70$ & $9.00 \pm 2.50$ & 6.86 \\
\hline & $\mathrm{RR}$ & $86.50 \%$ & $85.00 \%$ & $82.90 \%$ & $80.20 \%$ & $78.60 \%$ & $82.90 \%$ \\
\hline \multirow{3}{*}{$\mathrm{Cd}$} & YR & $2.80 \pm 0.60$ & $2.50 \pm 0.30$ & $2.10 \pm 0.40$ & $1.30 \pm 0.20$ & $2.20 \pm 0.30$ & 2.18 \\
\hline & $\mathrm{CW}$ & $0.30 \pm 0.10$ & $0.30 \pm 0.10$ & $0.30 \pm 0.10$ & $0.20 \pm 0.10$ & $0.40 \pm 0.10$ & 0.30 \\
\hline & $\mathrm{RR}$ & $89.30 \%$ & $88.00 \%$ & $85.70 \%$ & $84.60 \%$ & $81.80 \%$ & $86.20 \%$ \\
\hline
\end{tabular}

Table 2. Heavy metal concentrations $(\mathrm{mg} / \mathrm{kg})$ in the Yellow River $(\mathrm{YR})$ and constructed wetland $(\mathrm{CW})$ wetland substrate $(\mathrm{n}=3)$ at different developmental stages (I-V) of Bufo raddei.

\begin{tabular}{|c|c|c|c|c|c|}
\hline HMs & & $\mathrm{Cu}$ & $\mathrm{Zn}$ & $\mathrm{Pb}$ & $\mathrm{Cd}$ \\
\hline \multirow{4}{*}{ YR } & I & $26.90 \pm 2.76$ & $81.50 \pm 10.50$ & $18.50 \pm 3.53$ & $0.15 \pm 0.03$ \\
\cline { 2 - 6 } & II & $24.70 \pm 4.70$ & $78.70 \pm 11.40$ & $18.20 \pm 4.47$ & $0.14 \pm 0.04$ \\
\cline { 2 - 6 } & III & $27.40 \pm 5.72$ & $82.60 \pm 6.78$ & $17.60 \pm 3.39$ & $0.13 \pm 0.02$ \\
\cline { 2 - 6 } & IV & $27.20 \pm 3.62$ & $83.60 \pm 14.40$ & $18.30 \pm 4.42$ & $0.16 \pm 0.05$ \\
\hline \multirow{3}{*}{ CW } & V & $26.30 \pm 6.28$ & $82.10 \pm 13.50$ & $16.10 \pm 4.64$ & $0.15 \pm 0.05$ \\
\cline { 2 - 6 } & I & $21.60 \pm 0.27^{\mathrm{a} * *}$ & $53.50 \pm 0.38^{\mathrm{a} * *}$ & $16.30 \pm 0.12^{\mathrm{a}}$ & $0.02 \pm 0.01^{\mathrm{a} * *}$ \\
\cline { 2 - 6 } & II & $22.10 \pm 0.19^{\mathrm{b} *}$ & $54.90 \pm 1.10^{\mathrm{b} * *}$ & $17.10 \pm 0.60^{\mathrm{b}}$ & $0.03 \pm 0.01^{\mathrm{a} * *}$ \\
\cline { 2 - 6 } & III & $22.20 \pm 0.27^{\mathrm{b} * *}$ & $56.20 \pm 1.40^{\mathrm{c} * *}$ & $17.30 \pm 0.55^{\mathrm{b}}$ & $0.05 \pm 0.01^{\mathrm{b} * *}$ \\
\cline { 2 - 6 } & IV & $22.60 \pm 0.18^{\mathrm{b} * *}$ & $57.60 \pm 1.38^{\mathrm{d} * *}$ & $17.40 \pm 0.86^{\mathrm{b}}$ & $0.07 \pm 0.01^{\mathrm{c} * *}$ \\
\cline { 2 - 6 } & V & $23.10 \pm 0.21^{\mathrm{b} *}$ & $58.30 \pm 0.51^{\mathrm{d} * *}$ & $17.80 \pm 1.12^{\mathrm{b}}$ & $0.08 \pm 0.02^{\mathrm{c} * *}$ \\
\hline
\end{tabular}

Different superscript letters indicate significant differences between the developmental stages of $B$. raddei in the CW.

$* \mathrm{P}<0.05, * * \mathrm{P}<0.01$ for the difference between toads at the same stage from the $\mathrm{YR}$ and the $\mathrm{CW}$.

centrations of all of the HMs studied were decreased by the CW to below the permissible limits defined in the level III guidelines in the Chinese Surface Water Environmental Quality Standard (GB 3838-2002). Our results agreed with previously published results [5] confirming that CWs are effective at removing HMs from contaminated wastewater, and that the RRs are different for different metals. Moreover, it could be seen from the present results that the removal efficiency of CW on HMs would be different due to the status of water pollution in the YR as well as the growth cycle of the cattails. That is, during stages III-V the removal efficiency was relatively lower than stages I-II, which was attributed to the relatively slow growth of the cattails, which would in turn produce less biomass. This has been confirmed by previous studies [19, 26].
The $\mathrm{Cd}, \mathrm{Cu}, \mathrm{Pb}$, and $\mathrm{Zn}$ concentrations in the wetland substrate samples from the YR and CW are shown in Table 2. The HM concentrations were significantly higher in the YR sludge samples than in the CW substrate samples (except for $\mathrm{Pb}$ ) and, moreover, no significant variations in the YR water concentrations were found at any time, indicating that the HM concentrations in the YR were relatively stable. However, in Table 1 large differences were found in the concentrations of the HMs in the water from the YR during different periods due to the changes of pollutant emissions from the metal smelting factories and other pollution sources located in the upper reaches of the YR. Hence we concluded that the HM concentrations in the YR sludge had reached equilibrium after a long period of accumulation, and would not be easily changed by YR water quality. 
Table 3. Heavy metal concentrations $(\mathrm{mg} / \mathrm{kg})$ in toads $(\mathrm{n}=3)$ from the Yellow River (YR) and the constructed wetland $(\mathrm{CW})$ at different developmental stages.

\begin{tabular}{|c|c|c|c|c|c|}
\hline Site & Stage & $\mathrm{Cd}$ & $\mathrm{Cu}$ & $\mathrm{Pb}$ & $\mathrm{Zn}$ \\
\hline \multirow{4}{*}{ YR } & I & $0.82 \pm 0.13$ & $3.10 \pm 0.36$ & $4.18 \pm 0.62$ & $21.30 \pm 3.72$ \\
\cline { 2 - 6 } & II & $0.77 \pm 0.15$ & $4.65 \pm 0.28^{\mathrm{A}}$ & $4.40 \pm 0.85$ & $27.20 \pm 1.95^{\mathrm{a}}$ \\
\cline { 2 - 6 } & III & $1.29 \pm 1.32^{\mathrm{AB}}$ & $4.75 \pm 0.83^{\mathrm{A}}$ & $9.61 \pm 2.06^{\mathrm{AB}}$ & $32.90 \pm 3.61^{\mathrm{Ab}}$ \\
\cline { 2 - 6 } & IV & $0.75 \pm 0.07^{\mathrm{c}}$ & $3.97 \pm 0.38^{\mathrm{ab}}$ & $6.78 \pm 1.27^{\mathrm{Abc}}$ & $24.70 \pm 1.57^{\mathrm{bC}}$ \\
\hline \multirow{3}{*}{ CW } & V & $0.56 \pm 0.18^{\mathrm{cD}}$ & $4.51 \pm 0.25^{\mathrm{a}}$ & $7.13 \pm 1.33^{\mathrm{Abc}}$ & $19.20 \pm 2.14 \mathrm{~b}^{\mathrm{Cd}}$ \\
\cline { 2 - 6 } & I & $0.18 \pm 0.05^{* *}$ & $1.64 \pm 0.20^{* *}$ & $2.37 \pm 0.47^{* *}$ & $6.77 \pm 1.24 * *$ \\
\cline { 2 - 6 } & II & $0.22 \pm 0.04^{\mathrm{a} * *}$ & $2.07 \pm 0.14^{\mathrm{a} * *}$ & $2.94 \pm 0.27^{\mathrm{a} * *}$ & $7.76 \pm 1.61 * *$ \\
\cline { 2 - 6 } & III & $0.39 \pm 0.08^{\mathrm{AB} * *}$ & $2.57 \pm 0.23^{\mathrm{b} * *}$ & $5.74 \pm 0.82^{\mathrm{AB} * *}$ & $13.4 \pm 2.73^{\mathrm{AB} * *}$ \\
\cline { 2 - 6 } & IV & $0.26 \pm 0.03^{\mathrm{Ac} * *}$ & $2.17 \pm 0.38^{\mathrm{A} * *}$ & $4.61 \pm 0.94^{\mathrm{A} *}$ & $11.70 \pm 1.32^{\mathrm{A} * *}$ \\
\cline { 2 - 6 } & V & $0.29 \pm 0.06^{\mathrm{Ac} * *}$ & $2.25 \pm 0.15^{\mathrm{A} * *}$ & $5.81 \pm 0.13^{\mathrm{Ad} *}$ & $9.91 \pm 1.08^{\mathrm{acd} * *}$ \\
\hline
\end{tabular}

Compared with stage I, ${ }^{\mathrm{a}} \mathrm{P}<0.05 ;{ }^{\mathrm{A}} \mathrm{P}<0.01$.

Compared with stage II, ${ }^{b} \mathrm{P}<0.01$; ${ }^{\mathrm{B}} \mathrm{P}<0.01$.

Compared with stage III, ${ }^{\mathrm{C}} \mathrm{P}<0.05 ;{ }^{\mathrm{c}} \mathrm{P}<0.01$.

Compared with stage IV, ${ }^{\mathrm{d}} \mathrm{P}<0.05 ;{ }^{\mathrm{D}} \mathrm{P}<0.01$.

Compared with toads from the YR in the same stage, $* \mathrm{P}<0.05 ; * * \mathrm{P}<0.01$.

The accumulation of HM in sediment and the absorption by plants in the $\mathrm{CW}$ were two important mechanisms for reducing the HM concentrations in CW water [19]. In the present study, the $\mathrm{Cu}$ and $\mathrm{Pb}$ concentrations in the $\mathrm{CW}$ sediment changed little over time throughout the periods in our experiment, except between stages I and II, whereas the $\mathrm{Cd}$ and $\mathrm{Zn}$ concentrations increased significantly with time $(\mathrm{P}<0.05)$, indicating the rapid enrichment of these HMs in the CW sediment. Meanwhile, HM accumulation in the cattails was the same as our previous studies. By comparing the HM concentrations in the YR and $\mathrm{CW}$ water samples (Table 1), it can be illustrated that the CW system in the present study was quite effective at removing HMs from the contaminated YR water.

\section{Beneficial Effects of the CW on the Development of $B$. raddei}

The DNA damage levels, HM enrichment factors, liver coefficients, oxidative stress levels, and physiological indices of the toads living in the $\mathrm{CW}$ were recorded and compared with the values for the toads living in the YR water, to assess the effects of the $\mathrm{CW}$ on the development of $B$. raddei.

\section{The Effect of the CW on HM Enrichment in $B$. raddei}

As shown in Table 3, the concentrations of all four HMs in the toads followed a bell-shaped curve in all five developmental stages, reaching their highest values in stage III, both in the YR and the CW. The HM concentrations were significantly lower in the toads from the $\mathrm{CW}$ than in the toads from the YR, in all of the developmental stages
$(\mathrm{P}<0.05)$. We concluded that HM enrichment in the organisms living in the water could effectively indicate the level of HM contamination in the water. The $\mathrm{CW}$ reduced the HM concentrations in the toads living in the polluted water.

The results also indicate that HM enrichment in the toads was related to their developmental stage, presumably because metamorphosis occurred between stages I and III, meaning that the toads lived in the water constantly during that time, and the HMs were enriched within them, compared with the water, with time. Once the toads reached stage IV metamorphosis, they could leave the water and adapt to terrestrial life. After this, some HM could be excreted, gradually decreasing the HM concentrations within the toads' bodies [27].

\section{The Effect of the CW on the Development of $B$. raddei}

Toads with abnormal morphologies were studied to assess developmental disorders caused by HM pollution, and the types of malformations found were recorded. The malformations found included bobtailed tadpoles (18/1000, number of malformation tadpoles/total number of tadpoles, the same below), ectrodactyly tadpoles (4/1000), tadpoles with hind limbs growing on the tail (4/1000), tadpoles growing a single leg (7/1000), and ectrodactyly toads (3/1000), as shown in Fig. 2. Many other defects were also found in the toads from the YR but, surprisingly, no abnormalities were found in toads from the CW. Exposure to pollutants would increase the malformation frequency of amphibians, and these malformations are correlated with reduced moving speed and aberrant movements that might hence increase animal mortality [28]. It is wildely accepted that pollution-caused malformation might seriously affect 


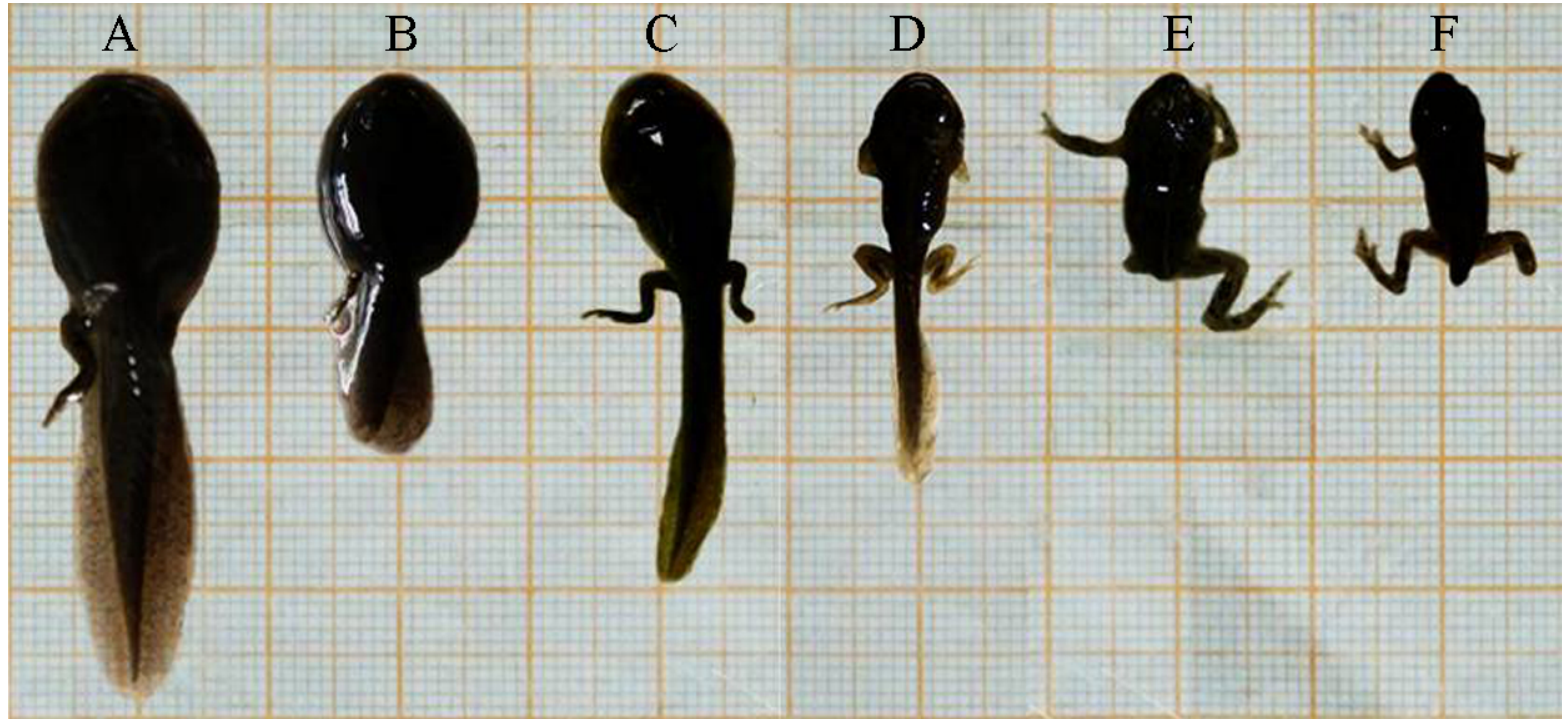

Fig. 2. Deformities found in toads (Bufo Raddei) from the Yellow River (A - normal, B - bobtail, C - ectrodactyly tadpole, $\mathrm{D}$ - hindlimbs growing on the tail, E - single leg, F - ectrodactyly toad).

individual fitness [29]. Taking into account that the toads in the $\mathrm{CW}$ were collected from $\mathrm{BY}$, an industrial city with heavy pollution background, it can be inferred that the $\mathrm{CW}$ system functions well in protecting amphibians from abnormalities.

It can be seen in Fig. 3 that the body lengths and weights were lower in toads from the YR than in toads from the $\mathrm{CW}$, and the differences were even significant at stage IV. These differences might be caused by pollution in the YR, whereas the $\mathrm{CW}$ decreased the effects of HM pollution and, therefore, was conducive to the normal development of the toads. Several studies have shown that thyroid-mediated metamorphosis can be induced by stress. For example, under natural conditions, crowding will accelerate the metamorphosis as an adaptive stress response [30]. It seems likely that environmental contaminants can also affect metamorphosis by inducing a stress response. One of the consequences of accelerated metamorphosis is that newly emerged juveniles are likely to be undersized [31], as was found in this study. Metamorphosis at a small size will have a negative effect on future fitness, growth, and overwinter survival [20]. Our results show that the CW functioned well in cleaning the HM-polluted water, and could provide protection from pollution for toads.

\section{The Effect of the CW on Physiological Indices and DNA Damage in B. raddei}

In addition to malformations and body size differences, physiological indices, including liver coefficients, ROS contents, T-AOC, and DNA oxidative damage levels, were examined to further explore the effects of the $\mathrm{CW}$ on the toads.

As shown in Table 4, the liver coefficients, ROS contents, and DNA oxidative damage levels were all significantly lower in the toads in the CW than in the toads in the YR, and the T-AOC index was higher in the toads in the CW. Antioxidant defenses are the primary mechanisms by


Fig. 3. The (a) body lengths and (b) body weights of toads Bufo raddei at different developmental stages in the Yellow River and the constructed wetland. $* \mathrm{P}<0.05$ and $* * \mathrm{P}<0.01$ represent for the difference between toads at the same stage from the Yellow River (YR) and the constructed wetland $(\mathrm{CW})$. 
Table 4. Liver coefficients, ROS contents, T-AOC levels, and DNA oxidative damage levels in Bufo raddei (n=3) at different developmental stages from the Yellow River (YR) and the constructed wetland (CW)

\begin{tabular}{|c|c|c|c|c|c|c|}
\hline & & I & II & III & IV & V \\
\hline \multirow{2}{*}{$\begin{array}{c}\text { Liver coefficient } \\
(\%)\end{array}$} & YR & $2.84 \pm 0.16^{\mathrm{c}}$ & $4.97 \pm 0.35^{\text {ab }}$ & $5.12 \pm 0.62^{\mathrm{a}}$ & $4.18 \pm 0.26^{\mathrm{b}}$ & $4.52 \pm 0.83^{\mathrm{ab}}$ \\
\cline { 2 - 7 } & $\mathrm{CW}$ & $2.13 \pm 0.22^{* \mathrm{c}}$ & $3.24 \pm 0.24^{* \mathrm{~b}}$ & $4.36 \pm 0.48^{* \mathrm{a}}$ & $3.21 \pm 0.35^{* * \mathrm{~b}}$ & $2.83 \pm 0.52^{* * \mathrm{bc}}$ \\
\hline \multirow{2}{*}{ ROS content (U) } & YR & $0.74 \pm 0.08^{\mathrm{b}}$ & $0.54 \pm 0.07^{\mathrm{e}}$ & $1.40 \pm 0.13^{\mathrm{a}}$ & $0.89 \pm 0.09^{\mathrm{c}}$ & $0.62 \pm 0.11^{\mathrm{b}}$ \\
\cline { 2 - 7 } & $\mathrm{CW}$ & $0.56 \pm 0.07^{* \mathrm{c}}$ & $0.42 \pm 0.06^{* \mathrm{c}}$ & $0.93 \pm 0.10^{* * \mathrm{a}}$ & $0.53 \pm 0.08^{* * \mathrm{~b}}$ & $0.36 \pm 0.02^{* * \mathrm{~d}}$ \\
\hline \multirow{2}{*}{$\begin{array}{c}\text { T-AOC level } \\
\text { (U/mg pro) }\end{array}$} & YR & $2.90 \pm 0.77^{\mathrm{abc}}$ & $2.49 \pm 0.55^{\mathrm{bc}}$ & $1.73 \pm 0.30^{\mathrm{d}}$ & $2.75 \pm 0.23^{\mathrm{b}}$ & $2.09 \pm 0.38^{\mathrm{ab}}$ \\
\cline { 2 - 7 } & $\mathrm{CW}$ & $4.11 \pm 0.77^{* \mathrm{a}}$ & $3.89 \pm 0.58^{* \mathrm{ab}}$ & $2.57 \pm 0.55^{* \mathrm{~b}}$ & $3.54 \pm 0.76^{* \mathrm{ab}}$ & $4.45 \pm 0.47^{* \mathrm{a}}$ \\
\hline \multirow{2}{*}{$\begin{array}{c}\text { DNA damage } \\
\text { level (\%) }\end{array}$} & YR & $35.7 \pm 3.28^{\mathrm{a}}$ & $33.9 \pm 1.86^{\mathrm{b}}$ & $38.7 \pm 5.62^{\mathrm{ab}}$ & $23.6 \pm 2.58^{\mathrm{c}}$ & $14.4 \pm 4.12^{\mathrm{d}}$ \\
\cline { 2 - 7 } & $\mathrm{CW}$ & $22.5 \pm 2.06^{* * \mathrm{ab}}$ & $19.1 \pm 4.45^{* * \mathrm{a}}$ & $20.9 \pm 3.26^{* * \mathrm{a}}$ & $13.11 \pm 2.48^{* * \mathrm{~b}}$ & $8.36 \pm 0.47 * \mathrm{c}$ \\
\hline
\end{tabular}

Different superscript letters mean there were significant differences between different developmental stages of $B$. raddei in the YR or in the $\mathrm{CW}, \mathrm{P}<0.05$. Compared with the $\mathrm{YR}$ in the same stage, ${ }^{*} \mathrm{P}<0.05,{ }^{*} * \mathrm{P}<0.01$.

which organisms compensate for oxidative damage caused by contact with substances that can cause oxidative effects [32]. ROS may be induced by a great number of substances, including HMs, phenols, and other organic pollutants [33]. We found a significant positive correlation between the ROS level and the total HM content $\left(\mathrm{R}^{2}=0.69, \mathrm{P}=0.03\right)$. High ROS levels could directly or indirectly decrease the antioxidative capacity of the toads, resulting in oxidative stress because of the impairment of cellular defense mechanisms, and leading to oxidative damage, such as genomic DNA damage, as shown in Table 4. The CW effectively decreased the HM concentrations in the YR water, and improved the T-AOC value, so the ROS and DNA oxidative damage levels were significantly lower $(\mathrm{P}<0.05)$ in the toads in the $\mathrm{CW}$ than in the toads in the YR. Similar results were found for the liver coefficients, that is, the $\mathrm{CW}$ system played a significant role in reducing the live coefficients of toads all through life stages. Live coefficients are an effective and sensitive index to monitor physiological changes in animals, and several studies have shown that heavy metal pollution would lead to an increase of live coefficients and hence cause liver injury [34]. The reducing of live coefficients in toads in $\mathrm{CW}$ would indicate the reducing of liver damage. Combined with other indicators like oxidative stress and ROS levels, the present study clarified that the improved water quality in the $\mathrm{CW}$ provided better living conditions for the toads.

Combined with the findings described above (that no toad abnormalities were found in the $\mathrm{CW}$ ), we concluded that the toad malformations found in the YR were probably caused by non-hereditary mutations rather than genetic mutations. Taking into account the fact that the oxidative DNA damage levels were higher during periods I-III than during stages IV and $\mathrm{V}$, our study demonstrates that the premetamorphosis stage is critical in phenotypic variations in amphibians.

Our results illustrate that $\mathrm{HM}$ enrichment in toads is closely related to their developmental stage, with stage III the most sensitive period for HM pollution. The liver coefficients, ROS contents, and DNA oxidative damage levels also exhibited bell-shaped curves and peaked at stage III, in both the $\mathrm{CW}$ and the YR. However, the T-AOC values reached minima at stage III (Table 4). It has been suggested [35] that during the critical period of transformation into an adult toad, reduced levels of glutathione (GSH) and catalase are required for the complete resorption of tail and gills, and intestinal remodeling, to be achieved. However, depletion of GSH always accompanies high ROS production [36], leading to high oxidative stress levels. It is quite possible, of course, that when the metamorphosis is complete (at stage IV), the toads will move away from the contaminated water, decreasing the HM concentrations within their bodies through the excretion processes mentioned above, which will help to mitigate oxidative damage caused by HM pollution.

\section{Conclusions}

The normal growth and development of amphibians in the upper YR is seriously threatened by HM pollution. Our study showed that HM pollution causes striking defects, enriched HM levels, and elevated oxidative damage in the toads. These results illustrate the urgency of cleaning the affected water and preventing further pollution. However, the CW system used for this study provided a good living environment for the toads, mainly by removing HMs efficiently from the water system. The HM removal rates from the water were in the order $\mathrm{Cd}>\mathrm{Pb}>\mathrm{Zn}>\mathrm{Cu}$, and each of the $\mathrm{HM}$ concentrations in the $\mathrm{CW}$ met the Grade III national water quality standard for surface water in China. For the first time, our study showed that the $\mathrm{CW}$ can provide better living environments for amphibians in contaminated areas, manifested in our study as lower HM concentrations, larger body sizes, and lower oxidative stresses in the toads $B$. raddei. We recommend that $\mathrm{CW}$ systems are promoted for cleaning polluted water and protecting amphibians' development. However, more research is needed about the postprocessing of the wetland substrate and plants saturated with HM. 


\section{Acknowledgements}

Our project was supported by the National Natural Science Foundations of China (Nos. 30770390 and 31300437) and the Science and Technology Program of Gansu Province (No. 090NKCA078). The analyses of metal elements were carried out in the Instrumental Analysis and Research Center of Lanzhou University. We especially thank Zheng-de Li and Yi-bing Su for helping us with sample collection and analyses of metal elements in the laboratory.

\section{References}

1. ZHANG T., XU D., HE F., ZHANG Y., WU Z. Application of constructed wetland for water pollution control in China during 1990-2010. Ecol. Eng. 47, (0), 189, 2012.

2. CHEN T. Y., KAO C. M., YEH T. Y., CHIEN H. Y., CHAO A. C. Application of a constructed wetland for industrial wastewater treatment: A pilot-scale study. Chemosphere. 64, (3), 497, 2006.

3. SONG X., YAN D., LIU Z., CHEN Y., LU S., WANG D. Performance of laboratory-scale constructed wetlands coupled with micro-electric field for heavy metal-contaminating wastewater treatment. Ecol. Eng. 37, (12), 2061, 2011.

4. ARROYO P., ANSOLA G., MIERA L. E. S. D. Effects of substrate, vegetation and flow on arsenic and zinc removal efficiency and microbial diversity in constructed wetlands. Ecol. Eng. 51, (0), 95, 2013.

5. KHAN S., AHMAD I., SHAH M. T., REHMAN S., KHALIQ A. Use of constructed wetland for the removal of heavy metals from industrial wastewater. J. Environ. Manage. 90, (11), 3451, 2009.

6. LIZAMA A. K., FLETCHER T. D., SUN G. Removal processes for arsenic in constructed wetlands. Chemosphere. 84, (8), 1032, 2011.

7. SZYCZEWSKI P., SIEPAK J., NIEDZIELSKI P., SOBCZYNSKI T. Research on Heavy Metals in Poland. Pol. J. Environ. Stud. 18, (5), 755, 2009.

8. CHENG Q., WANG W., WANG H., WANG ZHAO Z. Investigation of the heavy metal contamination of the sediments from the yellow river wetland nature reserve of zhengzhou, china. Iran J Public Health. 41, (3), 26, 2012.

9. LIU C., XU J., ZHANG P., DAI M. Heavy metals in the surface sediments in Lanzhou Reach of Yellow River, China. B. Environ. Contam. Tox. 82, (1), 26, 2009.

10. WANG Y., CHEN P., CUI R., SI W., ZHANG Y., JI W. Heavy metal concentrations in water, sediment, and tissues of two fish species (Triplohysa pappenheimi, Gobio hwanghensis) from the Lanzhou section of the Yellow River, China. Environ. Monit. Assess. 165, (1-4), 97, 2010.

11. DENOEL M., LIBON S., KESTEMONT P., BRASSEUR C., FOCANT J. F., DE PAUW E. Effects of a sublethal pesticide exposure on locomotor behavior: a video-tracking analysis in larval amphibians. Chemosphere. 90, (3), 945, 2013.

12. MASElLI V., POLESE G., RIPPA D., LIGRONE R., KUMAR RASTOGI R., FULGIONE D. Frogs, sentinels of DNA damage induced by pollution in Naples and the neighbouring Provinces. Ecotox. Environ. Safe. 73, (7), 1525, 2010.

13. BRÜHL C. A., SCHMIDT T., PIEPER S., ALSCHER A. Terrestrial pesticide exposure of amphibians: An underestimated cause of global decline? Sci. Rep. 3, 1135, 2013.
14. POLLET I., BENDELL-YOUNG L. I. Amphibians as indicators of wetland quality in wetlands formed from oil sands effluent. Environ. Toxicol. Chem. 19, (10), 2589, 2000.

15. ISNAS M., YEGIN E., CELIK I. Effects of omethoate on certain oxidative biomarkers in various tissues of frogs (Rana ridibunda) at acute exposure. Toxicol. Ind. Health. 28, (1), 27, 2012.

16. AMADO L. L., GARCIA M. L., RAMOS P. B., FREITAS R. F., ZAFALON B., FERREIRA J. L. R., YUNES J. S., MONSERRAT J. M. A method to measure total antioxidant capacity against peroxyl radicals in aquatic organisms: Application to evaluate microcystins toxicity. Sci. Total Environ. 407, (6), 2115, 2009.

17. HAYES T. B., FALSO P., GALLIPEAU S., STICE M. The cause of global amphibian declines: a developmental endocrinologist's perspective. J. Exp. Biol. 213, (6), 921, 2010.

18. HUANG D., ZHANG Y., WANG Y., XIE Z., JI W. Assessment of the genotoxicity in toad Bufo raddei exposed to petrochemical contaminants in Lanzhou Region, China. Mutat. Res. 629, (2), 81, 2007.

19. SI W., JI W., YANG F., LV Y., WANG Y., ZHANG Y. The function of constructed wetland in reducing the risk of heavy metals on human health. Environ. Monit. Assess. 181, (1-4), 531, 2011.

20. BRUNELLI E., BERNABÒ I., BERG C., LUNDSTEDTENKEL K., BONACCI A., TRIPEPI S. Environmentally relevant concentrations of endosulfan impair development, metamorphosis and behaviour in Bufo bufo tadpoles. Aquat. Toxicol. 91, (2), 135, 2009.

21. SEPA. Technical specifications requirements for monitoring of surface water and wastewater HJ/T 91-2002. pp. 1-54, 2002.

22. NAN Z., ZHAO C. Heavy Metal Concentrations in Gray Calcareous Soils of Baiyin Region, Gansu Province, P.R. China. Water Air Soil Pollut. 118, (1-2), 131, 2000.

23. ZHAO A. F. Preliminary studies on embryo development of Toad (Bufo raddei). Chinese Journal of Zoology, 26, 11, 1991.

24. ASSOCIATION A. V. M. 2000 report of the AVMA panel on euthanasia. J Am Vet Med Assoc. 218, 669, 2001.

25. ANDRIGHETTI-FROHNER C. R., KRATZ J. M., ANTONIO R. V., CRECZYNSKI-PASA T. B., BARARDI C. R., SIMOES C. M. In vitro testing for genotoxicity of violacein assessed by Comet and Micronucleus assays. Mutat Res. 603, (1), 97, 2006.

26. ROUSSEAUA D. P. L., LESAGE E., STORY A., VANROLLEGHEM P. A., DE PAUW N. Constructed wetlands for water reclamation. Des alination, 218, 181, 2008.

27. AKERSTROM M., BARREGARD L., LUNDH T., SALLSTEN G. The relationship between cadmium in kidney and cadmium in urine and blood in an environmentally exposed population. Toxicol Appl. Pharm. 268, (3), 286, 2013.

28. DAYTON G., FITZGERALD L. Competition, predation, and the distributions of four desert anurans. Oecologia. 129, (3), 430, 2001.

29. EGEA-SERRANO A., RELYEA R. A., TEJEDO M., TORRALVA M. Understanding of the impact of chemicals on amphibians: a meta-analytic review. Ecol Evol. 2, (7), 1382, 2012.

30. DENVER R. J. Proximate Mechanisms of Phenotypic Plasticity in Amphibian Metamorphosis. Am. Zool. 37, (2), 172, 1997.

31. MANN R. M., HYNE R. V., CHOUNG C. B., WILSON S. P. Amphibians and agricultural chemicals: Review of the 
risks in a complex environment. Environ. Pollut. 157, (11), 2903, 2009.

32. ANTUNES S. C., MARQUES S. M., PEREIRA R., GONCALVES F., NUNES B. Testing procedures for the determination of several biomarkers in different species, for environmental assessment of pollution. J. Environ. Monit. 12, (8), 1625, 2010

33. PATETSINI E., DIMITRIADIS V. K., KALOYIANNI M. Biomarkers in marine mussels, Mytilus galloprovincialis, exposed to environmentally relevant levels of the pesticides, chlorpyrifos and penoxsulam. Aquat Toxicol. 126, 338, 2013.
34. IAVICOLI I., LESO V., BERGAMASCHI A. Toxicological Effects of Titanium Dioxide Nanoparticles: A Review of In Vivo Studies. J Nanomater. 2012, 1, 2012.

35. MENON J., ROZMAN R. Oxidative stress, tissue remodeling and regression during amphibian metamorphosis. Comp. Biochem Phys. C. 145, (4), 625, 2007.

36. MACHO A., HIRSCH T., MARZO I., MARCHETTI P., DALLAPORTA B., SUSIN S. A., ZAMZAMI N., KROEMER G. Glutathione depletion is an early and calcium elevation is a late event of thymocyte apoptosis. J. Immunol. 158, (10), 4612, 1997. 
